Prof. D. Graham J. Shipley

School of Archaeology \& Ancient History

University of Leicester

Leicester

GB-LE1 7RH

\title{
L. P. HARTLEY'S THE GO-BETWEEN AND CHARLES MORGAN'S A BREEZE OF MORNING
}

L. P. Hartley claimed that when he was asked what gave him the idea for The Go-between ${ }^{1}$ he 'always found the question difficult to answer'. ${ }^{2}$ Yet the plot of the novel (hereinafter $G B$ ) shows remarkable similarities — which seem not to have been noticed — to Charles Morgan's A Breeze of Morning, published only two years earlier (hereinafter $B M$ ). ${ }^{3}$ Each story is told in the first person by a middle-aged man looking back to his childhood in the 1900s, and is topped and tailed with his retrospective reflections. At the time of the recollected events, each narrator is a thirteen-year-old schoolboy — modest, serious, middle-class — who is invited into the glamorous world of a grand English house. Each observes, and does not fully comprehend, the emotional relationships between several young adults, between two of whom he is asked to take a secret message or messages. Each has an important 'man to man' relationship with one of the protagonists. In both novels, the plot reaches a crisis as a

\footnotetext{
${ }^{1}$ L. P. Hartley, The Go-between (London, 1953).

${ }^{2}$ L. P. Hartley, 'Author's introduction', in The Go-between (New York, 2002; originally published 1963), 7-15, at p. 7; cf. A. Wright, Foreign Country: The Life of L. P. Hartley (London, 2001) (originally published London: André Deutsch, 1996), 167.

${ }^{3}$ C. Morgan, A Breeze of Morning (London, 1951).
} 
consequence of which the central female character marries an aristocrat for the sake of her family, against the dictates of her heart. Finally, the long-term impact of the events upon each boy is that he is left a perpetual outsider to such relationships of commitment. ${ }^{4}$

There are also, of course, differences between the plots. Morgan's setting is an unspecified year in the late 1900s; Hartley's is specifically the hot summer of 1900, and the weather becomes almost a character in the plot. ${ }^{5}$ Morgan's schoolboy, David Harbrook, has a sister; Hartley's, Leo Colston, is an only child. David is of higher social status, his father being (like Morgan's) a chief engineer for the railway; Leo's father was an unambitious provincial bank manager whose recent death has diminished the family's social standing. The houses to whose society the boys are admitted are also different: Morgan's a large residence on the edge of suburbia, belonging to an impoverished squire; Hartley's an aristocratic country house in full Victorian grandeur. David's actions have a positive impact upon the lovers, Leo's a negative. The young man whom David admires is his cousin, a studious lawyer; Leo's older friend is a working-class farmer. Finally, in $G B$ the crisis has a deadly resolution, the truelove relationship being passionately consummated only to be shattered through misguided actions that Leo has been manipulated into taking; in $B M$, David delivers the message that prevents an ill-judged elopement from taking place.

One contemporary critic, writing before the publication of $G B$, declared that Hartley's situations and characters were never derivative. ${ }^{6}$ A later writer, however, identified

\footnotetext{
${ }^{4}$ It is implied in $B M$ that David Harbrook has never married.

${ }^{5}$ See M. Hulme, '"Telling a different tale"', Climatic Change, 113.1 (2012), 5-21.

${ }^{6}$ P. H. Newby, The Novel, 1945-1950 (London, 1951), 35-6. J. Bayley, review of A. Wright, Foreign Country, London Review of Books, 18.8 (18 Apr. 1996), 26-7, quotes this passage as if Newby compares Graham Greene unfavourably with Hartley in this respect; Newby's comparison is, in fact, between Hartley and Joyce Cary.
} 
similarities between GB and a 1935 Graham Greene story, The Basement Room. ${ }^{7}$ While the similarities of the moral situations are real, however, the plot and atmosphere have little in common, chiefly because Greene's story involves a seven-year-old boy—not an 'adolescent' as Davison claims - whose perceptions of space, time, and causation place him still in a dreamlike relationship to reality. It may be worth adding that as recently as March 1950 Greene had received an Oscar nomination for his adaptation of the story as the screenplay of Carol Reed's film The Fallen Idol (1948); Hartley may have been aware of this too.

Tangye Lean's review of $B M^{8}$ points to similarities between that novel and Turgenev's First Love, which Morgan would certainly have acknowledged since he was a devotee of that work ${ }^{9}$ and wrote about it at some length. ${ }^{10}$ Also relevant, if tangentially, are the points of contact that Lean identifies between BM and Alain-Fournier's Le Grand Meaulnes (together with other representatives of 'the French school') as well as a plot device in Thomas Mann's Dr Faustus. Any of these predecessors may have resonated with Hartley as well as with Morgan. They are not, however, the point of the present note; for there is evidence, seemingly undetected hitherto, that a more immediate inspiration for $G B$ lay closer to hand, in Hartley's personal knowledge of $B M$.

The evidence is superficially incontrovertible: a review of $B M$ appears under Hartley's name in the Sunday Times for 30 September $1951 .{ }^{11}$ It is worth pausing, however, to note that

\footnotetext{
${ }^{7}$ R. A. Davison, 'Graham Greene and L. P. Hartley', Notes and Queries, 211 [n.s. 13]. 3 (1966), 101-2. Davison's surname is misprinted as Davidson; see correction at $\underline{N \& Q}, 211$ [n.s. 13]. 6 (1966), 266.

${ }^{8}$ T. Lean, review of C. Morgan, A Breeze of Morning, Spectator (20 Sept. 1951), 28.

${ }^{9}$ E. Lewis (ed.), Selected Letters of Charles Morgan (London, 1967), 171, no. 109.

${ }^{10}$ C. Morgan, The Writer and his World: Lectures and Essays (London, 1960), 174-98.

${ }^{11}$ L. P. Hartley, review of C. Morgan, A Breeze of Morning, Sunday Times, 6702 (30
} 
Hartley did not always write his own reviews: before the second world war, family and friends sometimes helped him at times of exceptional pressure by ghosting his work. ${ }^{12}$ Nevertheless, there is no evidence that after the war he continued to call upon friends to cover for him; many members of his Venice circle, indeed, had dispersed or died. In 1951 he was still reviewing at a great pace: in September alone there are thirteen of his pieces (in three batches) in the Sunday Times. All bear the stamp of his generosity and display his characteristic attention to details of style and plot.

The review of $B M$ was thus certainly written before Hartley wrote $G B$, a rapid process that can be dated precisely: he began work in May $1952 .{ }^{13}$ Why did he not later perceive, or reveal, a connection that now seems obvious?

Hartley and Morgan knew each other, at least by correspondence, and had long respected one another's work: Hartley commissioned work from Morgan in 1920, and Morgan hoped to do the same in return in $1922 .{ }^{14}$ By the early 1950 s, each was at the pinnacle of his

Sept. 1951), 3. It is quoted on the jacket of the Reprint Society's 1953 edition of $B M$, where it came to my attention; and again on the jacket of C. Morgan, Challenge to Venus (1957).

${ }^{12}$ Wright, Foreign Country, 112.

${ }^{13}$ Ibid., 166, gives the month; the year can be calculated from the adjacent pages. (Hartley, 'Author's introduction', gives no indication.) D. Brooks-Davies, 'Introduction', in L. P. Hartley, The Go-between (London, 1997), xi-xxix, at p. xv, documents the month when H. began, and H.'s own statement on 19 Oct. 1952 that he was already revising the MS (no source is cited). The same date range is given by C. Tóibín, 'Introduction', in L. P. Hartley, The Go-between (New York, 2002), v-xiii, at pp. ix-x, and A. Smith, 'The Go-between by L. P. Hartley', Guardian (17 June 2011); neither cites a source (though Tóibín clearly draws extensively upon Wright, Foreign Country).

${ }^{14}$ Wright, Foreign Country, 63 and 69 respectively. 
reputation. Even though $B M$ was just one among many new novels that Hartley was reading in 1952, it is hard to believe he did not remember it, especially given his extremely positive review, which identifies the core of the plot as 'the reactions of a thirteen-year-old schoolboy to grown-up events and feelings' and describes David as '[w]ithdrawn in his youth-dream, observant but not fully comprehending'. He praises 'the effortlessly evoked atmosphere of the period, with its leisurely tempo and its feeling of security', features that are equally apparent in $G B$ and are, indeed, a refrain through much of Hartley's own work. His comment that 'The book's limitation is its lack of continuous force: the whole conception has not the energy of its parts' could almost stand as a manifesto for his contrasting approach in $G B$.

I do not mean to argue in any way that Hartley plagiarizes Morgan. As remarked above, some features of $G B$ 's plot may have been drawn from Greene's story rather than from $B M$. More importantly, Hartley has created his own plot and his own moral agenda, focusing on specific concerns that (as Wright has shown) are almost ubiquitous in his novels, notably sexual isolation and the incapacity to commit. I do not mean to suggest, either, that Hartley seized on $B M$ as offering good material that he could exploit, but later deliberately refused to acknowledge the debt. Rather, I suggest that Morgan's new evocation of salient features of Hartley's emotional landscape — the 1900s, class differences, the feeling of 'looking in' at the adult emotional world—-stirred his profoundest memories, some of them painful. The passion with which he applied himself to $G B$ is reflected in the speed with which he completed the book, about five months. ${ }^{15}$ Something had prompted him to engage with his particular moral

\footnotetext{
${ }^{15}$ Ibid., 170 (without documentation). Brooks-Davies, 'Introduction', xv, quotes H.'s
} statement in a letter of 19 Oct. 1952 (no doubt destroyed, like most of his papers, after his sister Norah's death: Wright, Foreign Country, 274) that he was revising the MS. The date of October is repeated by Tóibín, 'Introduction', x, and Smith, "Go-between,", neither citing a source. 
and sexual concerns more directly than ever before, more intensely even than in his Eustace and Hilda trilogy (1944-7).

These concerns, it now seems probable, were linked to real events. There are striking similarities between the names of persons and places in $G B$ and the names of actual people connected with an episode in summer 1909, when Hartley stayed with a school-friend at his parents' country house in Norfolk and appears to have witnessed, or been party to, traumatic events similar to those that embroil Leo. ${ }^{16}$ Hartley claimed in 1963 that 'there was little resemblance between the two visits', ${ }^{17}$ but his emotional reaction to specific features of Joseph Losey's 1971 feature film of $G B$ is evidence that Leo's experiences were in some way his. ${ }^{18}$ Perhaps the turmoil unleashed by re-engaging with these memories obscured, by its very brightness, Hartley's recollection of having read $B M$; or perhaps the overwhelming importance of $G B$ to his self-exploration made him unwilling to acknowledge any external influence.

More speculatively, in his review of $B M$ Hartley may have unintentionally hinted that he saw the connection of Morgan's novel with his own life. At the start of $B M$, David Harbrook is said to be 'at the end of [his] fourteenth year'. ${ }^{19}$ Hartley in his review chooses to call him, rather, 'a thirteen-year-old schoolboy'; ${ }^{20}$ the same age, but expressed differently. The choice of words may be revealing: thirteen had been Hartley's own age in the summer of $1909 .^{21}$

I thank the staff of the British Library newspaper collection at Colindale for their

\footnotetext{
${ }^{16}$ Wright, Foreign Country, 31-3, 169, 253-4.

${ }^{17}$ Hartley, 'Author's introduction', 10-11.

${ }^{18}$ Wright, Foreign Country, 32-3.

${ }^{19}$ Morgan, Breeze of Morning, 4.

${ }^{20}$ Hartley, review of A Breeze of Morning.

${ }^{21}$ He was born on 30 Dec. 1895.
} 
assistance, and Martin Stannard for helpful advice.

University of Leicester

GRAHAM SHIPLEY 